\title{
Perancangan Sistem Informasi Kepegawaian Pada PT. Bakri Karya Sarana Batam
}

\author{
Zuli Astari ${ }^{1}$, Desi Pibriana ${ }^{* 2}$, Rusbandi ${ }^{3}$ \\ 1,2,3 STMIK MDP; Jalan Rajawali No. 14 Palembang, Telp: (0711)376400 \\ 1,2,3 Jurusan Sistem Informasi, STMIK MDP, Palembang

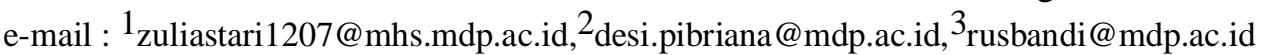

\begin{abstract}
Abstrak
PT Bakri Karya Sarana merupakan perusahaan yang bergerak di bidang penyedia jasa atau outsourcing. Dalam proses pengelolaan data kepegawainya PT Bakri Karya Sarana masih memiliki beberapa kendala yaitu terdapat pada perekrutan pegawai baru, absensi pegawai, data izin, cuti, mutasi, promosi, demosi, pengunduran diri, surat peringatan pegawai, penilaian pegawai lapangan dan penilaian kualitas dari klien. Tujuan penelitian ini adalah merancang dan membuat sistem informasi kepegawaian berbasis website pada PT Bakri Karya Sarana. Metodologi yang digunakan dalam penelitian ini adalah metodologi iterasi yang terdiri dari tahap perencanaan, analisis masalah, perancangan, implementasi dan pemeliharaaan. Dengan dirancangnya sistem informasi kepegawaian ini dapat membantu dan mempermudah kinerja bagian HRD dalam mengelola data kepegawaian mulai dari proses perekrutan pegawai baru, absensi pegawai, data izin, cuti, mutasi, promosi, demosi, pengunduran diri, surat peringatan pegawai, penilaian pegawai lapangan, penilaian kualitas dari klien dan semua laporan dapat diterima oleh direktur dengan cepat dan akurat.
\end{abstract}

Kata kunci: sistem informasi kepegawaian, outsourcing, metodologi iterasi.

\begin{abstract}
PT Bakri Karya Sarana is a company which focused on service providers or outsourcing. In the process of managing its employee data, PT Bakri Karya Sarana still has several obstacles, such as the new employees reqruitments, employee attendance, permit data, leave, mutation, promotion, demotion, resignation, employee warning letters, field staff appraisal and quality assessment from clients. The purpose of this research is to design and create a website-based personnel information system at PT Bakri Karya Sarana. The methodology used in this research is an iterative methodology consisting of planning, problem analysis, design, implementation and maintenance. With this design information system, it can help and simplify HRD performance in managing employees data starting from the process of recruiting new employees, employee attendance, permit data, leave, mutation, promotion, demotion, resignation, employee warning letters, field employee assessment, assessment of the quality of the client and all reports can be received by the director quickly and accurately.
\end{abstract}

Keywords: Personnel Information System, Outsourcing, Iteration Methodology.

\section{PENDAHULUAN}

$\mathrm{T}$ eknologi informasi sangat dibutuhkan disegala bidang untuk mendukung proses bisnis yang ada pada sebuah organisasi maupun perusahaan. Salah satu kemajuan tekonolgi tersebut yaitu dengan adanya komputer. Dengan adanya komputer dapat membantu pekerjaan manusia menjadi lebih praktis, cepat dan mudah. Pada PT Bakri Karya Sarana telah memanfaatkan teknologi komputer yaitu MS. Excel untuk beberapa pengelolaan administrasi 
kepegawaian akan tetapi hal tersebut dirasakan kurang maksimal dikarenakan banyaknya jumlah pegawai dan penggunaan MS. Excel tidak dapat mengintegrasikan data-data pegawai menyebabkan banyak terjadi kendala-kendala. Kendala yang terjadi terdapat pada perekrutan pegawai baru, berkas lamaran menumpuk menyebabkan HRD sulit menyeleksi berkas lamaran. Absensi pegawai, masih dilakukan secara manual yang menyebabkan kesalahan pencatatan, rekapitulasi rentan hilang dan menyebabkan manipulasi jam kerja. Data izin dan izin, pegawai harus mengambil form cuti dan izin ke kantor dimana proses tersebut membutuhkan waktu lama. Jatah cuti yang dimiliki oleh pegawai sebanyak 12 (dua belas) hari selama setahun, hal ini juga tertuang pada Undang-Undang Ketenagakerjaan Pasal 79 Ayat 2 UU No. 13 Tahun 2003 yang menyatakan cuti tahunan sekurang-kurangnya 12 (dua belas) hari kerja setelah pekerja/buruh yang bekerja selama 12 (dua belas) bulan secara terus menerus [1].

Pada proses mutasi, promosi, demosi dilihat dari penilaian pegawai. Menurut penelitian sebelumnya promosi sebagai suatu penghargaan/hadiah bagi karyawan yang memiliki prestasi tinggi sedangkan demosi merupakan sejenis sanksi/hukuman bagi karyawan yang prestasi kerjanya dinilai rendah oleh manajemen perusahaan. Mutasi suatu perubahan posisi/ jabatan/tempat/pekerjaan yang dilakukan baik secara horizontal maupun ertical [2]. Pengunduran diri, pegawai harus mengambil surat pengunduran diri kekantor dibagian HRD. Surat peringatan pegawai sulit dimonitoring HRD dan Direktur, selain itu tidak adanya penilaian klien terhadap pegawai outsourcing dari PT Bakri Karya Sarana. Dengan adanya sistem informsai kepegawaian ini diharapkan dapat membantu dan mempermudah dalam proses perekrutan hingga proses pengunduran diri pegawai serta mempermudah dalam proses pembuatan laporan.

\section{METODE PENELITIAN}

\subsection{Metode Penelitian}

Penelitian ini dilakukan dengan tahapan-tahapan sebagai berikut:

a. Wawancara, dilakukannya wawancara ini untuk mendapatkan informasi yang akurat dari narasumber dengan menyampaikan beberapa pertanyaan tertentu kepada narasumber untuk mendapatkan informasi yang akurat.

b. Observasi, dilakukannya proses pengamatan untuk menggambarkan segala sesuatu yang berkaitan dengan kebutuhan didalam sebuah organisasi atau perusahaan.

c. Studi Pustaka, segala usaha yang dilakukan untuk mendapatkan infromasi yang relevan dengan topik penelitian dari berbagai sumber.

\subsection{MetodologiPengembangan}

Metodologi yang digunakan dalam pengembangan sistem informasi kepegawaian pada PT Bakri Karya Sarana Batam adalah metodologi iterasi. Metode iterasi memerlukan penyelesaian analisis, desain dan implementasi karena penting untuk mengembangkan satu bagian sistem baru secara menyeluruh dan menempatkannya ke dalam operasi secepat mungkin. Setelah "versi" sistem tersebut diimplementasikan, strategi berikutnya adalah melakukan beberapa analisis, desain, dan implementasi tambahan untuk merilis sistem versi berikutnya. Pengulangan-pengulangan ini berlanjut sampai semua bagian dari keseluruhan sistem informasi telah diimplementasikan [3]. Metode iterasi mempunyai beberapa fase, yaitu:

1. Permulaan Sistem

Permulaan sistem ini menentukan pemecahan masalah, lingkup, tujuan, yang diperlukan untuk memecahkan masalah atau kesempatan yang ada.

2. Analisis Sistem

Analisis sistem ditujukan untuk menyediakan tim proyek pemahaman yang lebih menyeluruh terhadap masalah-masalah dan kebutuhan-kebutuhan yang sistem. 


\section{Desain Sistem}

Selama desain sistem pada awalnya akan mengeksplorasi solusi teknis alternatif. Setelah alternatif teknis dipilih dan disetujui fase desain sistem mengembangkan dan spesifikasi teknis yang dibutuhkan untuk mengimplementasikan database, antarmuka pengguna dan yang dibutuhkan sistem informasi.

4. Implementasi Sistem

Langkah terakhir dalam proses pengembangan sistem adalah implementasi sistem. Implementasi sistem mengkonstrusi sistem informasi baru dan menempatkannnya kedalam operasi. Selama implementasi sistemlah perangkat keras dan perangkat lunak sistem yang baru diinstal dan diuji.

\section{HASIL DAN PEMBAHASAN}

\subsection{Permulaan Sistem}

Pemulaan sistem ini dilakukan untuk melakukan pemecahan masalah yang ada kemudian ditentukan ruang lingkupnya untuk menentukan batasan-batasan sistem yang akan dirancang. Kemudian menentukan tujuan dari melakukan perancangan suatu sistem.

\subsection{Analisis Sistem}

Analisis sistem ditujukan untuk seseorang yang bertanggung jawab atas penelitian dengan pemahaman yang lebih menyeluruh terhadap masalah-masalah dan kebutuhan-kebutuhan yang memicu bisnis atau organisasi[3].

\subsubsection{Analisis Masalah} berikut:

Untuk menganalisis permasalahan yang ada, digunakan analisis PIECES, yaitu sebagai

\section{Peformance}

Lamanya dalam merekap absensi dan mencari rekapitulasi absensi pegawai dikarenakan proses rekap absensi masih menggunakan kertas rekapitulasi timesheet absen dimana kertas rekapitulasi timesheet tersebut juga menumpuk.

Sulit menyeleksi berkas lamaran calon pegawai baru menyebabkan proses seleksi berkas lamaran menjadi lama.

Direktur, bagian keuangan dan admin BPJS sering lama menerima laporan datadatakepegawai dikarenakan hanya mengandalkan laporan dari HRD.

\section{Information}

Tidak updatenya informasi mengenai laporan mutasi, demosi, promosi dan pengunduran diri yang diterima oleh direktur, bagian keuangan dan admin BPJS serta tidak updatenya informasi mengenai cuti dan izin karena HRD lupa memberikan laporan tersebut.

Informasi surat peringatan yang di dapat perpegawai sulit dimonitoring oleh HRD dan direktur.

Tidak akuratnya informasi rekapitulasi absensi dan peritungan cuti pegawai dikarenakan sering terjadi kesalahan pada rekapitulasi.

\section{Economic}

Perusahaan akan merugi karena menggaji pegawai yang mengundurkan diri dan memberikan gaji lebih kepada pegawai yang seharusnya gajinya berubah lebih rendah sesuai dengan perubahan upah, pegawai akan merugi karena perusahaan tidak memberikan gajinya lebih tinggi sesuai dengan perubahan upah hal ini terjadi karena tidak updatenya informasi laporan mutasi, demosi, promosi yang diterima bagian keuangan. 
Pegawai akan merugi apabila perusahaan terlambat memberikan gaji karena proses rekap absensi yang lama dan terjadi kesalahan pada perekapan absensi membuat gaji yang diterima pegawai tidak sesuai dengan kehadirannya.

\section{Control}

Rentan terjadi manipulasi jam kerja pegawai dan terjadi kehilangan berkas-berkas data pegawai.

Tidak akuratnya laporan absensi pegawai karena kurangnya pengendalian terhadap pencatatan absensi dan rekap absensi pegawai.

Sering terjadi kesalahan perhitungan sisa cuti pegawai karena perhitungan sisa cuti pegawai pada excel masih dihitung manual tidak bisa menggunakan rumus.

\section{Efficiency}

Beban kerja yang ditimbulkan lebih banyak karena proses pencatatan absensi dengan rekapitulasi absensi yang tidak akurat dan lamanya proses rekapitulasi absensi serta pencarian rekapitulasi absensi yang diperlukan.

6. Service

Layanan perusahaan pada pengajuan cuti dan izin pegawai yang sulit karena harus datang kekantor untuk mengambil form cuti dan izin.

Layanan perusahaan terhadap pemberian gaji yang rentan tertunda kepada pegawai akan merugikan pegawai.

\subsubsection{Analisis Kebutuhan}

Berdasarkan analisis masalah pada sistem lama diatas, maka kebutuhan sistem yang harus dipenuhi ada 2 kategori, yaitu:

\subsubsection{Kebutuhan Fungsional}

Kebutuhan fungsional adalah jenis kebutuhan yang berisi proses-proses apa saja yang nantinya dilakukan oleh sistem [4]. Kebutuhan fungsional yang harus dipenuhi oleh sistem berdasarkan analisis masalah yang telah diuraikan meliputi:

1. Sistem harus dapat membantu dalam proses perekapan absensi dan rekrutmen yang nantinya akan menjadi laporan yang akurat dan mempercepat dalam pencarian rekapitulasi absensi dan rekrutmen.

2. Sistem harus dapat membuat proses rekrutmen dan perekapan rekrutmen menjadi lebih efektif untuk mempermudah HRD dalam menyeleksi pegawai baru serta memudahkan HRD dalam mencari rekapitulasi rekrutmen yang dibutuhkan.

3. Sistem harus dapat mempermudah klien dalam melakukan penilaian terhadap pegawai yang outsourcing di perusahaan mereka.

4. Sistem harus dapat menghasilkan laporan penilaian kualitas dari klien dengan cepat sehingga proses evaluasi kinerja pegawai berdasarkan penilaian klien juga menjadi lebih cepat.

5. Sistem harus dapat mempermudah pegawai dalam mengajukan cuti dan izin sehingga HRD juga dipermudahkan untuk memvalidasinya.

6. Sistem harus dapat membuat proses perhitungan sisa cuti pegawai menjadi akurat sehingga pegawai tidak bisa menggambil cuti melebihi sisa cuti mereka.

7. Sistem harus dapat mempermudah HRD dan direktur dalam memonitoring surat peringatan yang didapat perpegawai.

8. Sistem harus dapat merekap seluruh data yang nantinya akan menjadi laporan dan adanya fitur laporan yang dapat diakses oleh direktur, bagian keuangan dan admin BPJS 


\subsubsection{Kebutuhan Non Fungsional}

Kebutuhan non fungsional adalah tipe kebutuhan yang berisi properti perilaku yang dimiliki oleh sistem [4]. Kebutuhan non fungsional yang telah diuraikan, kemudian dirangkum dalam tabel 1 dengan klasifikasi PIECES framework.

Tabel 1. Kebutuhan Non Fungsional

\begin{tabular}{|c|c|}
\hline $\begin{array}{c}\text { Jenis } \\
\text { Kebutuhan } \\
\text { Non-functional }\end{array}$ & Penjelasan \\
\hline $\begin{array}{l}\text { Kinerja } \\
\text { (Performance) }\end{array}$ & 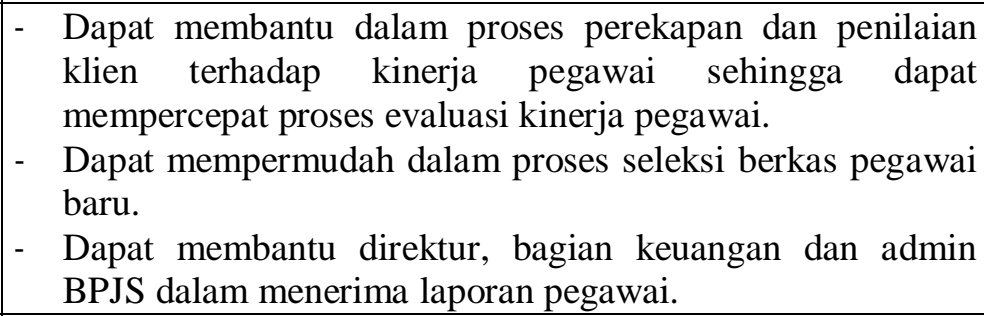 \\
\hline $\begin{array}{l}\text { Informasi } \\
\text { (Information) }\end{array}$ & $\begin{array}{l}\text { - Data mengenai informasi laporan pegawai dan laporan cuti } \\
\text { serta izin menjadi lebih update. } \\
\text { - Dapat memberikan informasi surat peringatan yang di } \\
\text { dapat perpegawai dapat dimonitoring oleh HRD dan } \\
\text { direktur. } \\
\text { - Dapat memberikan informasi lebih akurat terhadap proses } \\
\text { rekapitulasi absensi dan informasi perhitungan cuti. }\end{array}$ \\
\hline $\begin{array}{l}\text { Segi Ekonomi } \\
\text { (Economic) }\end{array}$ & $\begin{array}{l}\text { Dapat membantu perusahaan meminimalisir kerugian } \\
\text { dikarenakan tidak updatenya data-data pegawai }\end{array}$ \\
\hline $\begin{array}{l}\text { Pengontrolan } \\
\text { Sistem } \\
\text { (Control) }\end{array}$ & $\begin{array}{l}\text { - Dapat lebih terkontrol dalam absensi pegawai sehingga } \\
\text { tidak ada manipulasi jam kerja dan rekapitulasi data } \\
\text { pegawai dapat terkontrol secara berkala. } \\
\text { - Pengendalian terhadap pencatatan absensi dan rekap } \\
\text { absensi pegawai dan perhitungan sisa cuti pegawai menjadi } \\
\text { lebih akurat. }\end{array}$ \\
\hline $\begin{array}{l}\text { Efisiensi Sistem } \\
\text { (Efficiency) }\end{array}$ & 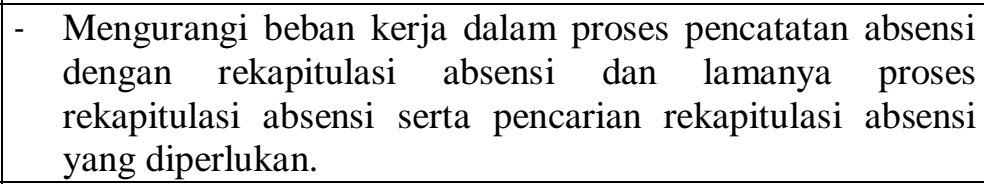 \\
\hline $\begin{array}{l}\text { Pelayanan Sistem } \\
\text { (Service) }\end{array}$ & $\begin{array}{l}\text { - Sistem ini dapat mempermudah pegawai pada pengajuan } \\
\text { cuti dan izin pegawai. } \\
\text { - Memberikan data-data yang akurat dan lengkap sehingga } \\
\text { dapat membantu perusahaan terhadap pemberian gaji yang } \\
\text { rentan tertunda kepada pegawai yang dapat merugikan } \\
\text { pegawai. }\end{array}$ \\
\hline
\end{tabular}

\subsection{Desain Sistem}

Selama desain sistem pada awalnya akan mengeksplorasi solusi teknis alternatif. Setelah alternatif teknis dipilih dan disetujui fase desain sistem mengembangkan cetak biru (blueprint) dan spesifikasi teknis yang dibutuhkan untuk mengimplementasikan database, program, antarmuka pengguna dan jaringan yang dibutuhkan sistem informasi [3]. 


\subsubsection{Diagram Dekomposisi}

Diagram dekomposisi digambarkan untuk mempartisi sistem menjadi sub sistem dan atau fungsi logika. Diagram dekomposisi untuk sistem yang akan dirancang dapat dilihat pada Gambar 1 .

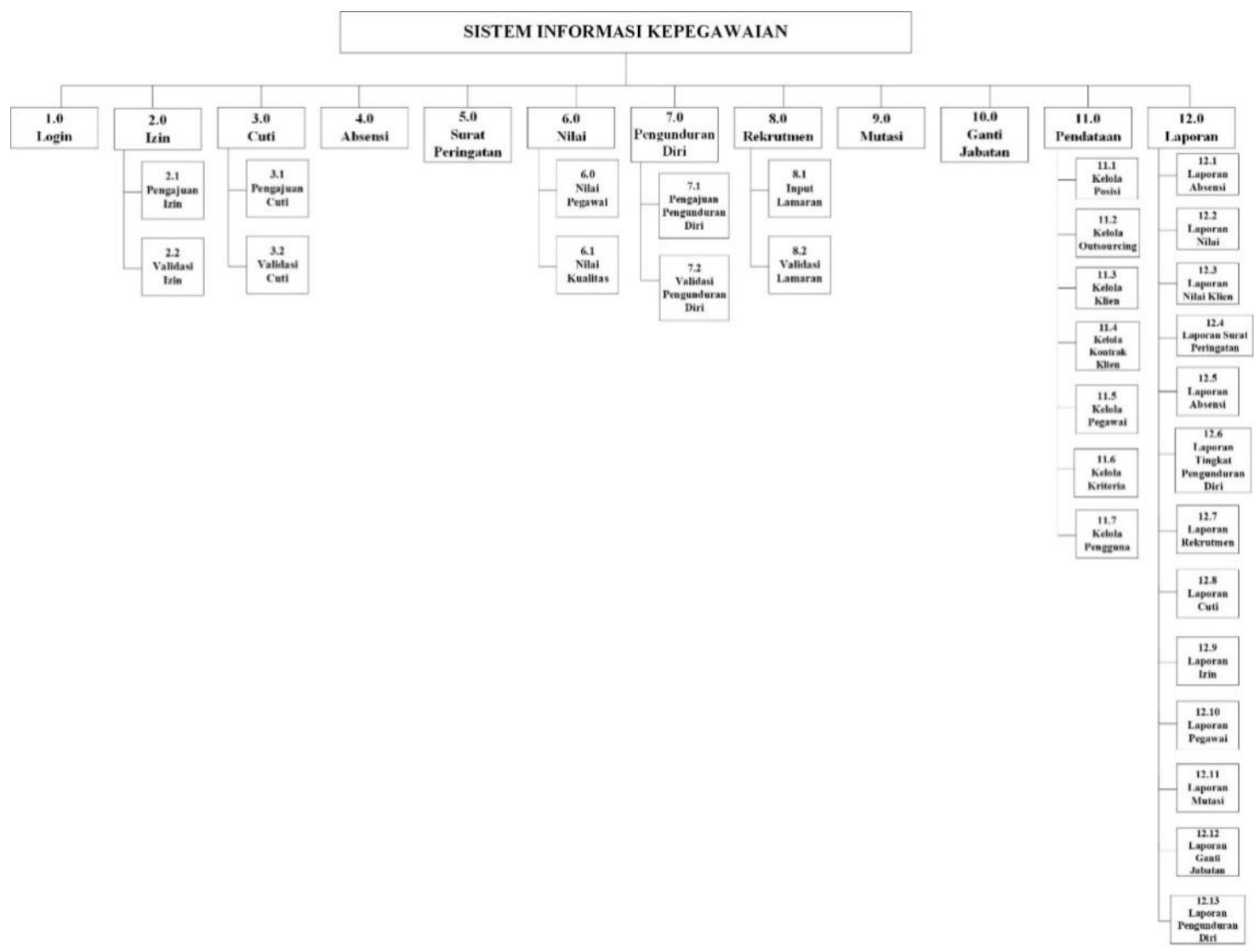

Gambar 1. Diagram Dekomposisi Sistem yang Dirancang

Pada Gambar 1 digambarkan bahwa Sistem Informasi Kepegawaian dipartisi menjadi subsistem yang terdiri dari login, izin, cuti, absensi, surat peringatan, nilai, pengunduran diri, rekrutmen, mutasi, ganti jabatan, pendataan serta laporan. Subsistem izin dibagi lagi menjadi lebih kecil, yakni subsistem pengajuan izin dan validasi izin oleh HRD. Subsistem cuti dibagi menjadi pengajuan cuti dan validasi cuti oleh HRD. Subsistem nilai dibagi menjadi nilai pegawai dan nilai kualitas. Subsistem pengunduran diri dibagi menjadi pengajuan pengunduran diri dan validasi pengunduran diri. Subsistem rekrutmen dibagi menjadi 2 yakni input lamaran dan validasi lamaran oleh HRD. Subsisem pendataan dibagi menjadi 7 yakni kelola posisi, kelola outsourcing, kelola klien, kelola kontrak klien, kelola pegawai, kelola kriteria, kelola pengguna.

Subsistem laporan dibagi menjadi 13 yakni laporan absensi, laporan nilai, laporan nilai klien, laporan surat peringatan, laporan absensi, laporan tingkat pengunduran diri, laporan rekrutmen, laporan cuti, laporan izin, laporan pegawai, laporan mutasi, laporan ganti jabatan, laporan pengunduran diri.

\subsubsection{Data Flow Diagram (DFD)}

Suatu proses penggambaran grafik aliran infromasi yang diaplikasikan sebagai data yang mengalir dari (input) dan keluaran (output) [5]. 


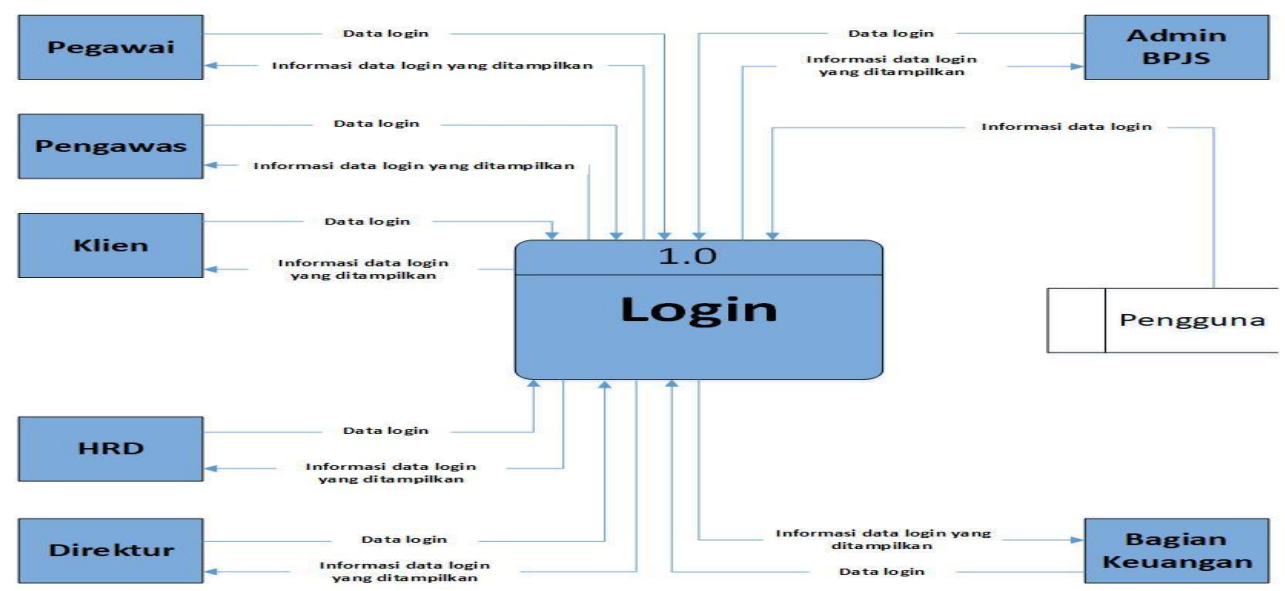

Gambar 2. Sistem Informasi yang Dirancang

Pada proses login, satu-satunya entitas yang tidak melakukan login adalah calon pegawai baru. Disini, calon pegawai baru dapat bersentuhan langsung dengan sistem yang akan dirancang, yaitu dengan memasukkan berkas lamaran calon pegawai baru. Semua user yang melakukan login mendapat validasi username dan password dari datastore user.

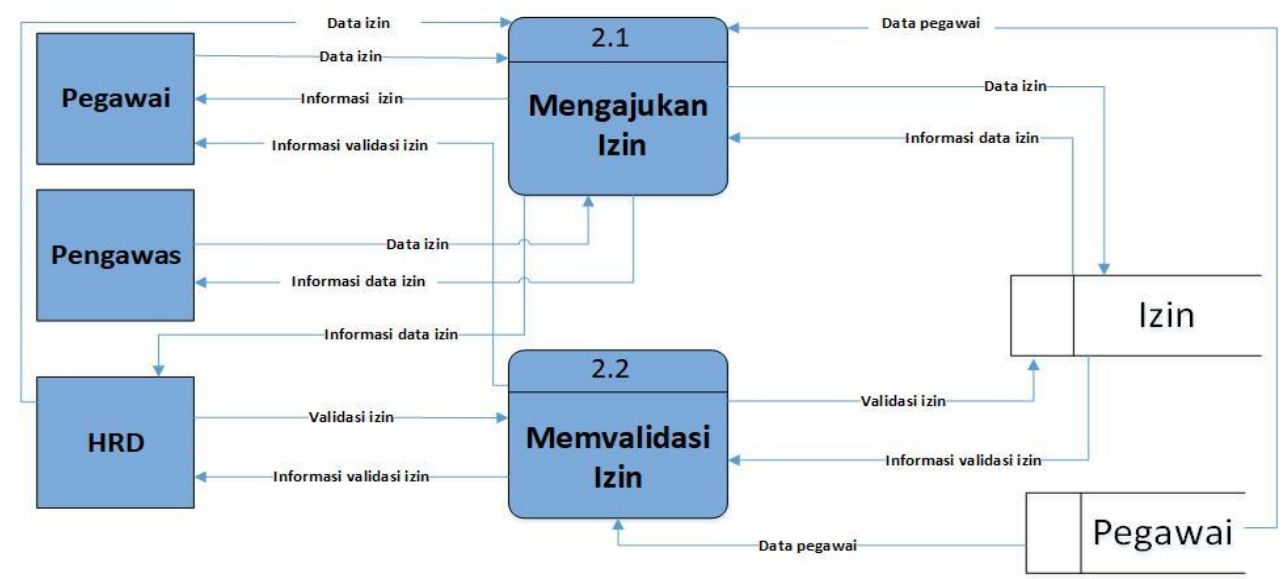

Gambar 3. Sistem Informasi yang Dirancang

Proses izin pada DFD Level 2, yaitu pengajuan izin dan validasi izin. Pengajuan izin ini dilakukan oleh pegawai dan pengawas dengan mengisi form izin. Sementara validasi izin ini merupakan izin yang telah diajukan oleh pegawai atau pengawas ke HRD dan akan divalidasi oleh HRD. 


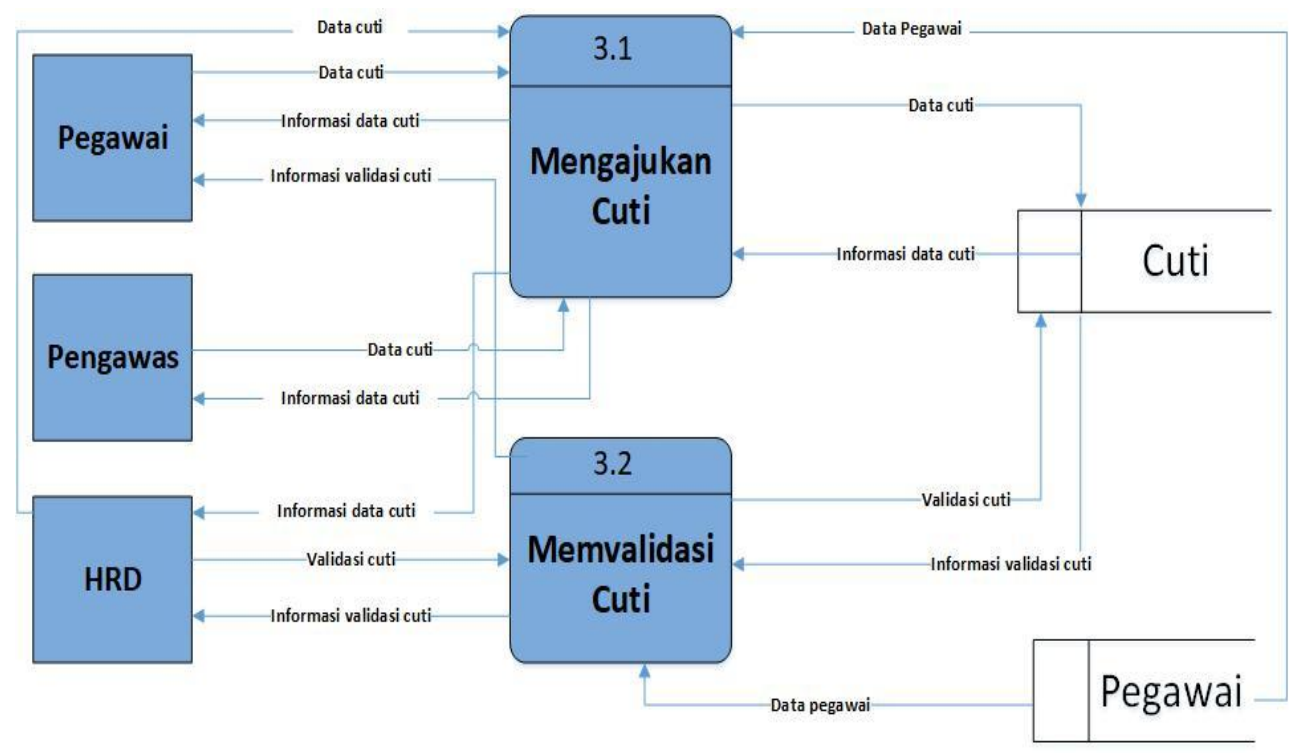

Gambar 4. Sistem Informasi yang Dirancang

Proses cuti pada DFD Level 2, yaitu pengajuan cuti dan validasi cuti. Pengajuan cuti ini dilakukan oleh pegawai dan pengaws dengan mengisi form cuti. Sementara validasi cuti ini merupakan form yang telah diajukan oleh pegawai atau pengawas ke hrd dan akan divalidasi oleh hrd.

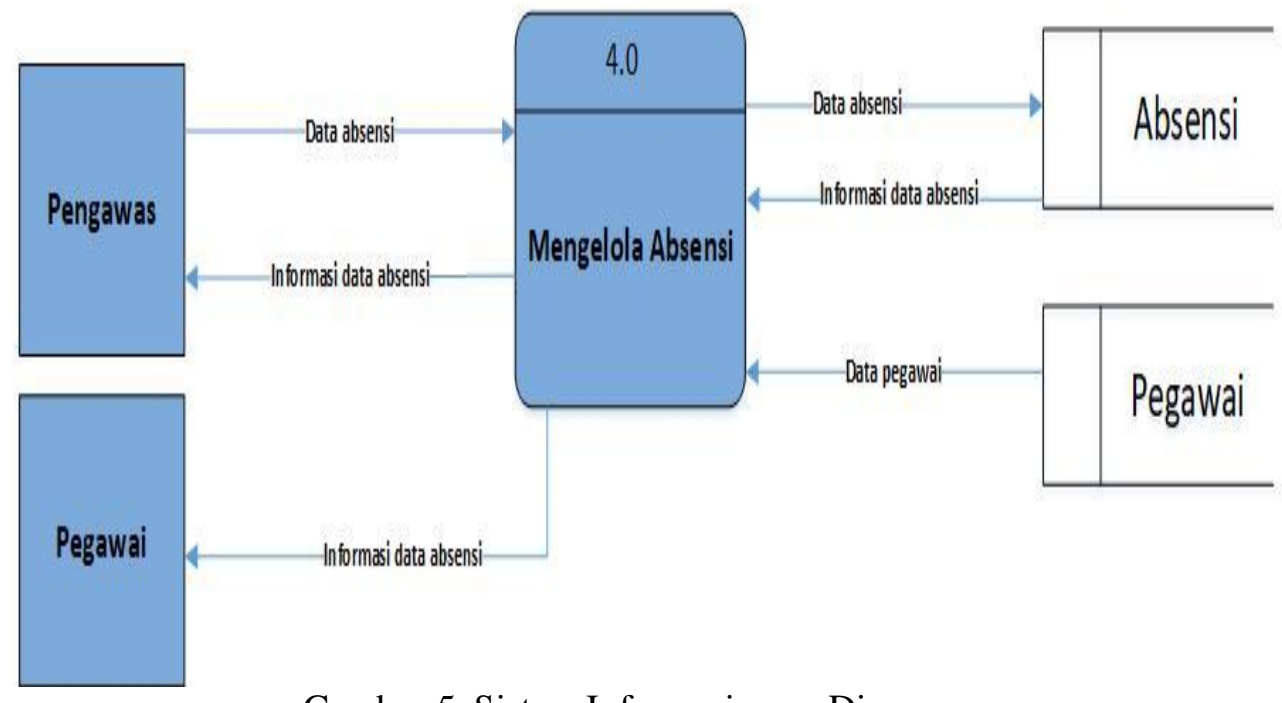

Gambar 5. Sistem Informasi yang Dirancang

Proses absensi menjadi proses yang lebih rinci lagi pada DFD Level 2. Disini pengawas dapat menginput absen pegawai dan pegawai dapat melihat absensi mereka. 


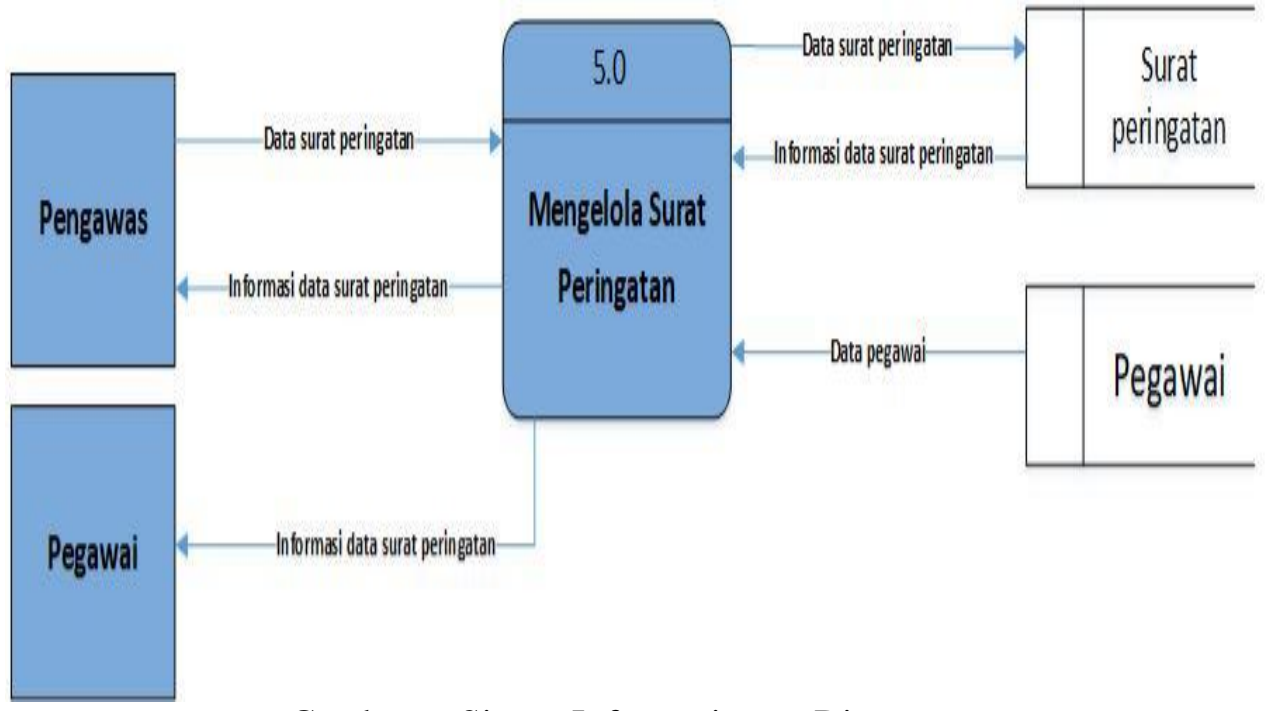

Gambar 6. Sistem Informasi yang Dirancang

Proses surat peringatan lebih rinci lagi pada DFD Level 2. Disini pengawas dapat menginput surat peringatan yang didapat perpegawai dan pegawai dapat melihat surat peringatan yang didapatnya.

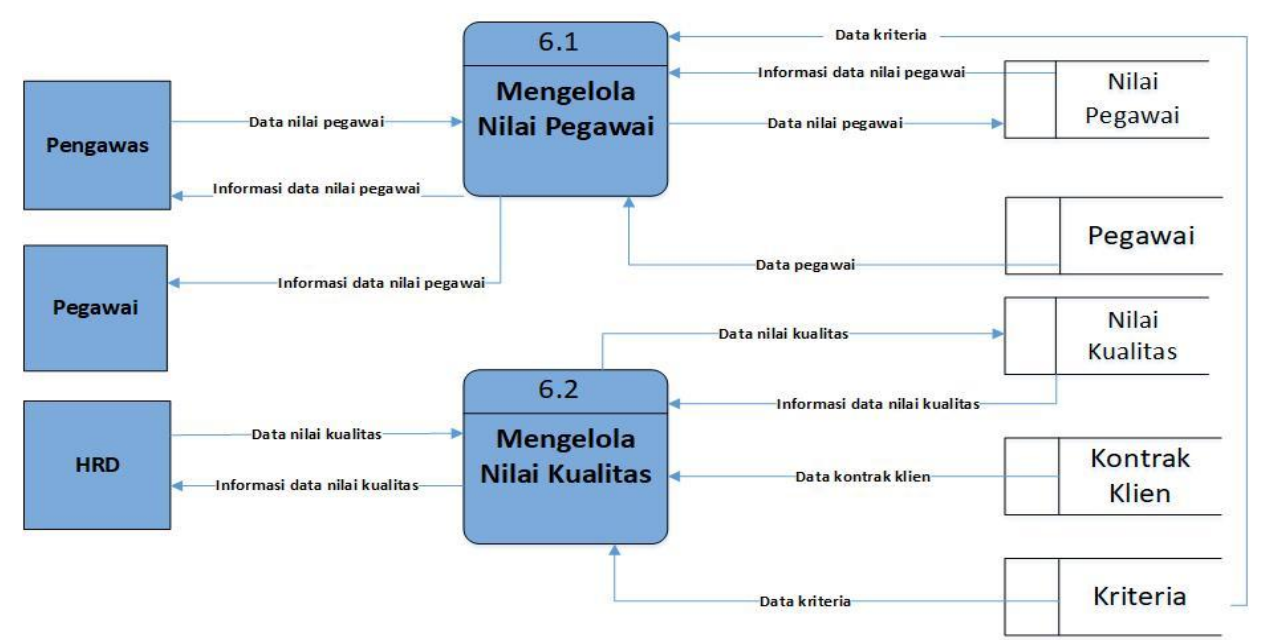

Gambar 7. Sistem Informasi yang Dirancang

Proses nilai pada DFD Level 2, yaitu nilai kualitas dan nilai pegawai. Nilai kualitas nilai yang diberikan kepada pegawai oleh klien dengan mengisi nilai pada form penilaian kualitas. Sementara nilai pegawai nilai yang diberikan kepada pegawai oleh pengawas. 


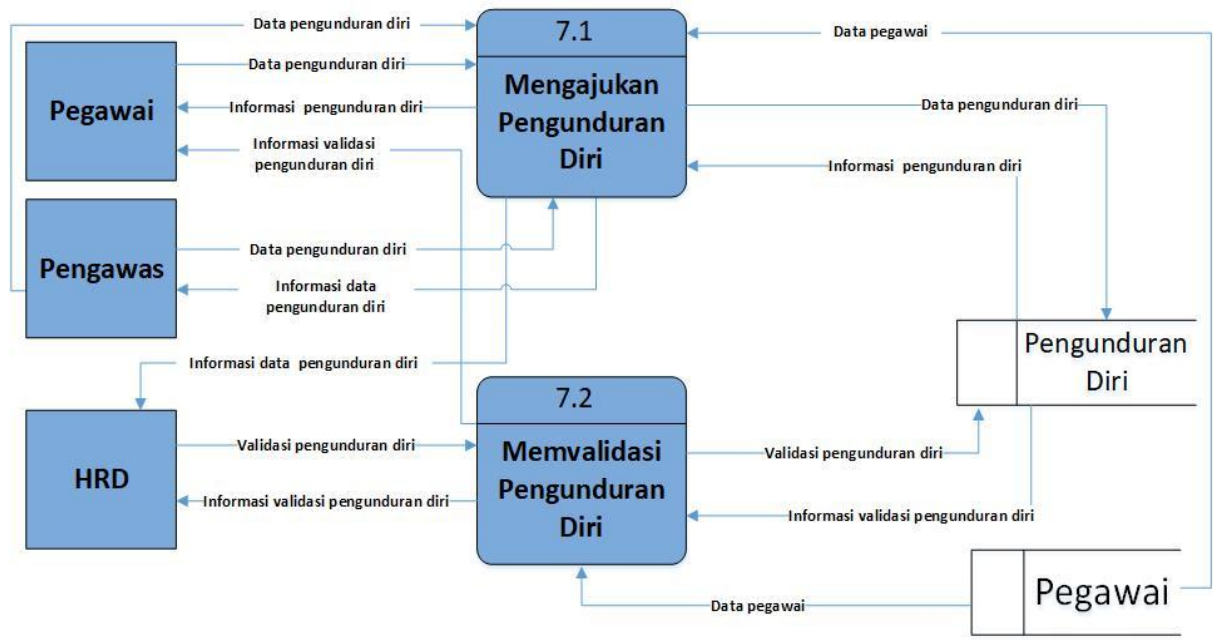

Gambar 8. Sistem Informasi yang Dirancang

Proses pengunduran diri pada DFD Level 2 dipecah menjadi 2, yaitu pengajuan pengunduran diri dan validasi pengunduran diri. Pengajuan pengunduran diri ini dilakukan pegawai dan pengawas dengan mengisi form pengunduran diri. Sementara validasi pengunduran diri ini merupakan form yang telah diajukan oleh pegawai atau pengawas ke HRD dan akan divalidasi oleh HRD.

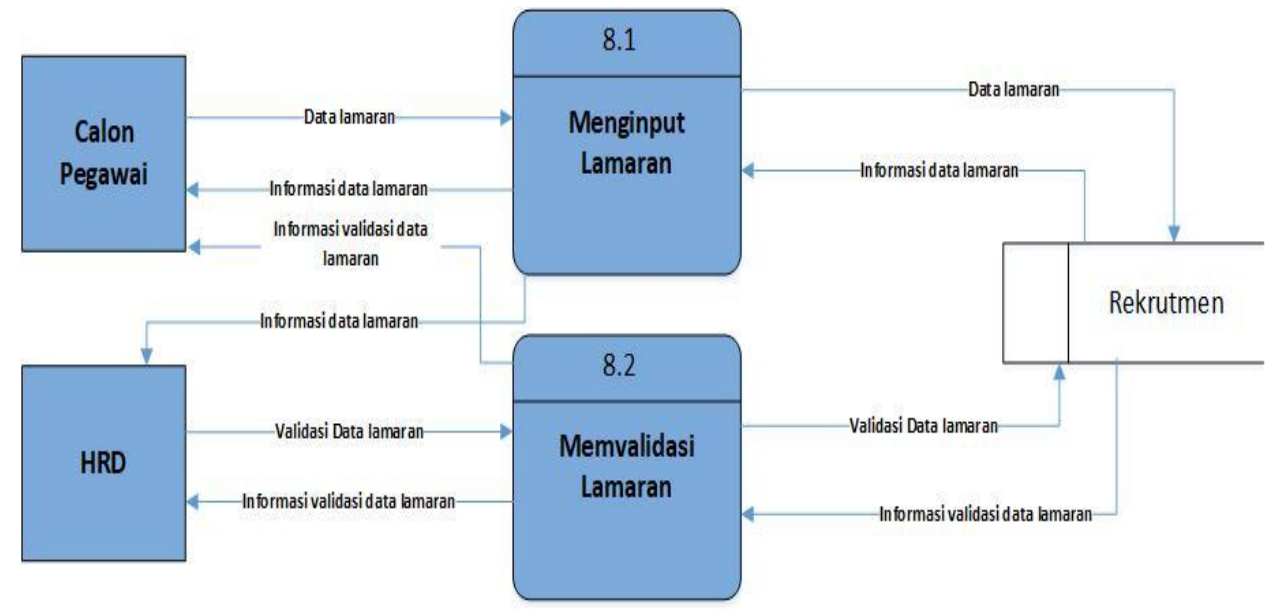

Gambar 9. Sistem Informasi yang Dirancang

Proses rekrutmen pada DFD Level 2, yaitu menginput lamaran dan validasi lamaran. Menginput lamaran ini dilakukan calon pegawai, sementara validasi lamaran ini merupakan validasi dari HRD terhadap lamaran yang telah diinput calon pegawai. 


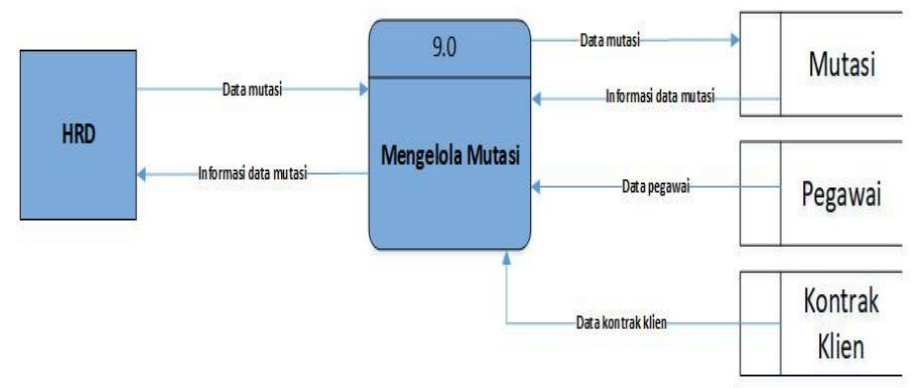

Gambar 10. Sistem Informasi yang Dirancang

Proses mutasi tidak dipecah menjadi proses yang lebih rinci lagi pada DFD Level 2. Disini HRD dapat menginput pegawai yang akan dimutasi. Pada proses mutasi terdapat 3 datastore yaitu datastore mutasi, pegawai dan kontrak klien.

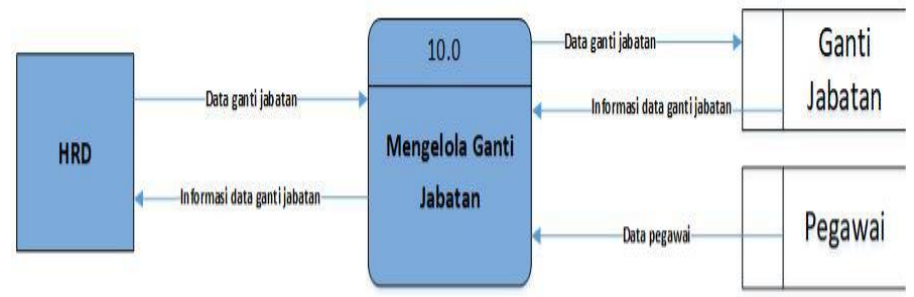

Gambar 11. Sistem Informasi yang Dirancang

Proses Ganti Jabatan tidak dipecah menjadi proses yang lebih rinci lagi pada DFD Level 2. Disini HRD dapat menginput pegawai yang akan di promosi atau demosikan.

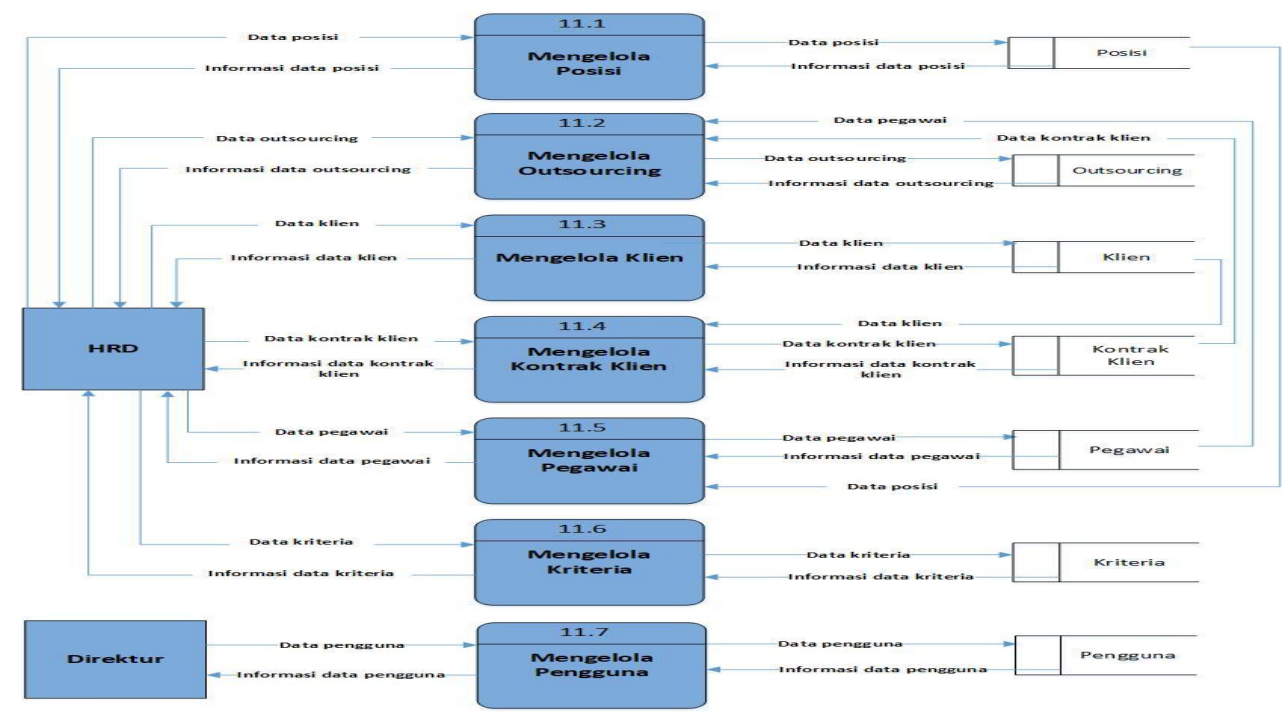

Gambar 12. Sistem Informasi yang Dirancang

Proses Pendataan dipecah menjadi 7 proses pada DFD level 2, yaitu pendataan pegawai, posisi, klien, kontrak klien, outsourcing, kriteria dan pengguna. 


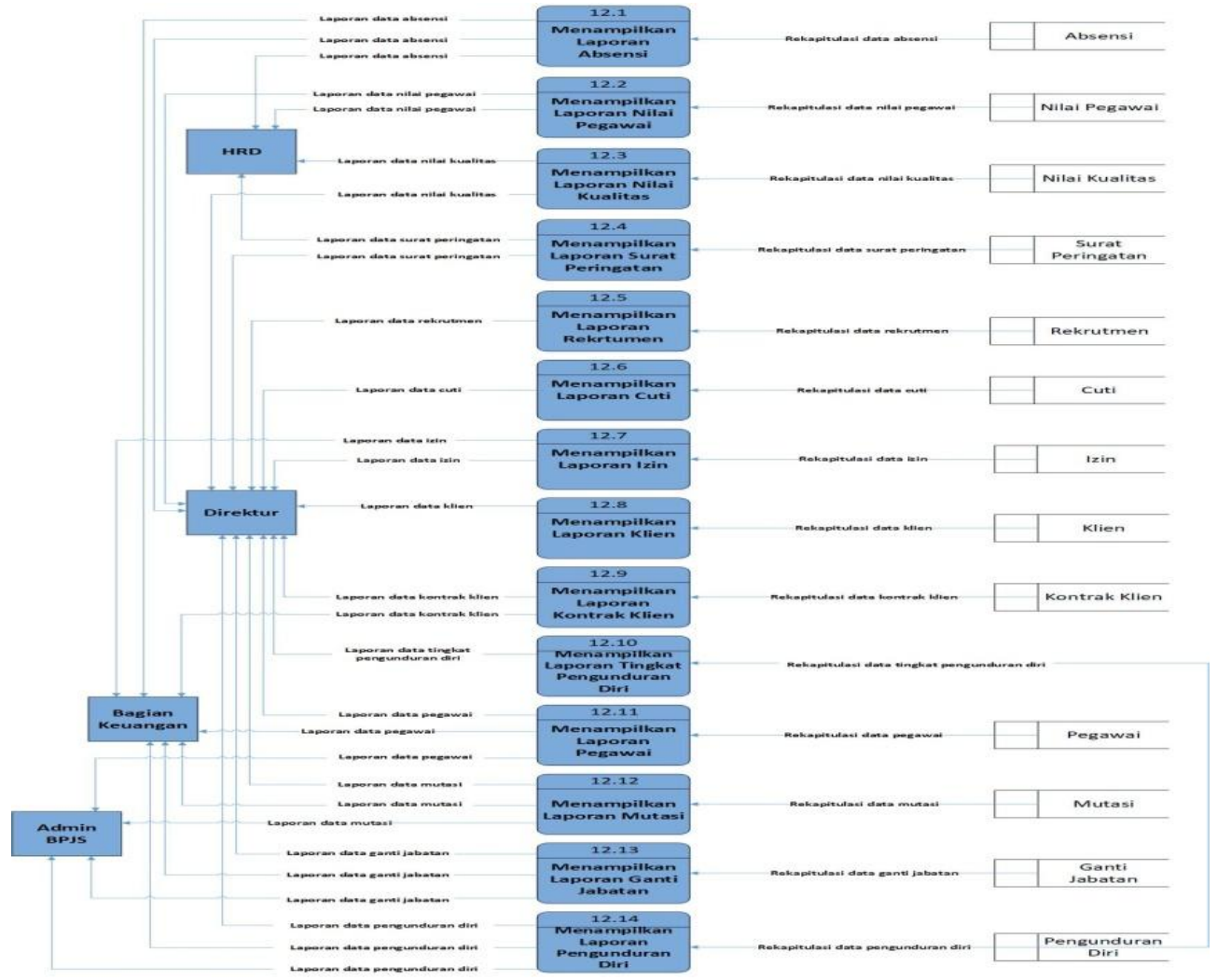

Gambar 13. Sistem Informasi yang Dirancang

Proses Laporan dipecah menjadi 14 proses pada DFD level 2, yaitu laporan pegawai, laporan klien, laporan kontrak klien, laporan absensi, laporan mutasi, laporan ganti jabatan, laporan cuti, laporan izin, laporan pengunduran diri, laporan rekrutmen, laporan nilai kualitas, laporan nilai pegawai, laporan tingkat pengunduran diri dan laporan surat peringatan yang masing-masing diambil dari datastore pegawai, klien, kontrak klien, absensi, mutasi, ganti jabatan, cuti, izin, pengunduran diri, rekrutmen, nilai kualitas, nilai pegawai, dan surat peringatan.

\subsubsection{Entity Relationship Diagram (ERD)}

ERD adalah pemodelan awal yang dikembangkan berdasarkan teori himpunan dalam bidang matematika untuk pemodelan basis data relasional [5]. Rancangan ERD yang diusulkan untuk sistem yang dirancang dapat dilihat pada gambar 3, dimana pada ERD dalam gambar 3 terdapat 17 entitas yang terdiri dari pengguna, rekrutment, posisi, klien, kontrak_klien, outsourcing, pegawai, surat_peringatan, cuti, izin, pengunduran_diri, absensi, nilai_kualitas, nilai_pegawai, ganti_jabatan, mutasi dan kriteria. Setiap entitas memiliki atribut masing-masing yang telah disesuaikan dengan form-form yang berlaku di PT Bakri Karya Sarana. 


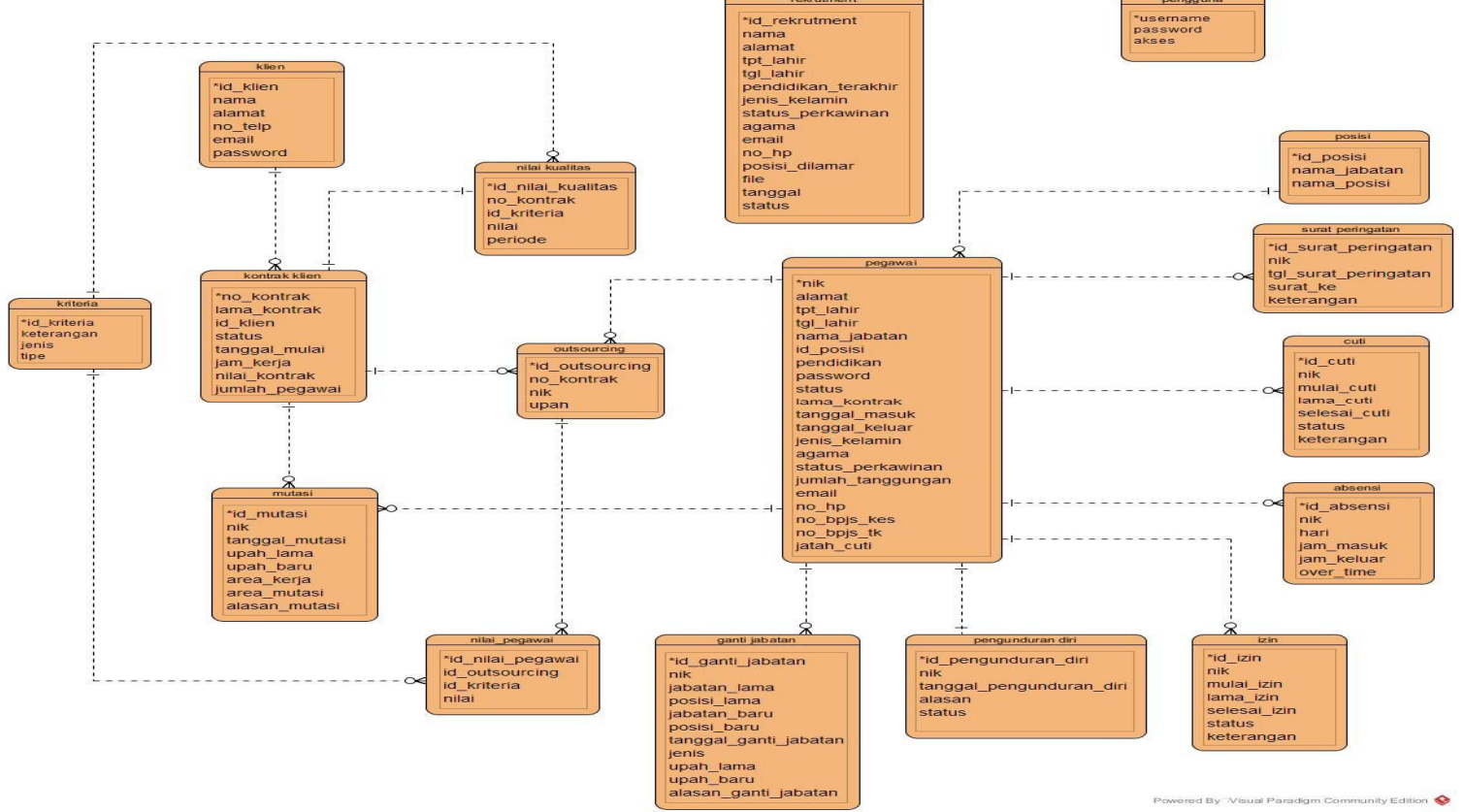

Gambar 14. Diagram ERD Sistem yang Dirancang

\subsubsection{Rancangan Antar Muka Sistem yang Diusulkan}

Rancangan antarmuka pengguna merupakan tampilan dimana pengguna berinteraksi dengan sistem [4]. Berikut ini adalah rancangan antar muka sistem yang diusulkan.

\subsubsection{Rancangan Antarmuka Beranda Hak Akses Direktur}

Rancangan antar muka beranda hak akses direktur ini adalah halaman utama yang menunjukkan hak akses direktur, dimana direktur berhak mengakses kelola pengguna, laporan pegawai, laporan klien, laporan kontrak klien, laporan absensi, laporan mutasi, laporan ganti jabatan, laporan cuti, laporan izin, laporan pengunduran diri, laporan rekrutmen, laporan nilai kualitas, laporan nilai pegawai, laporan tingkat pengunduran diri dan laporan surat peringatan.

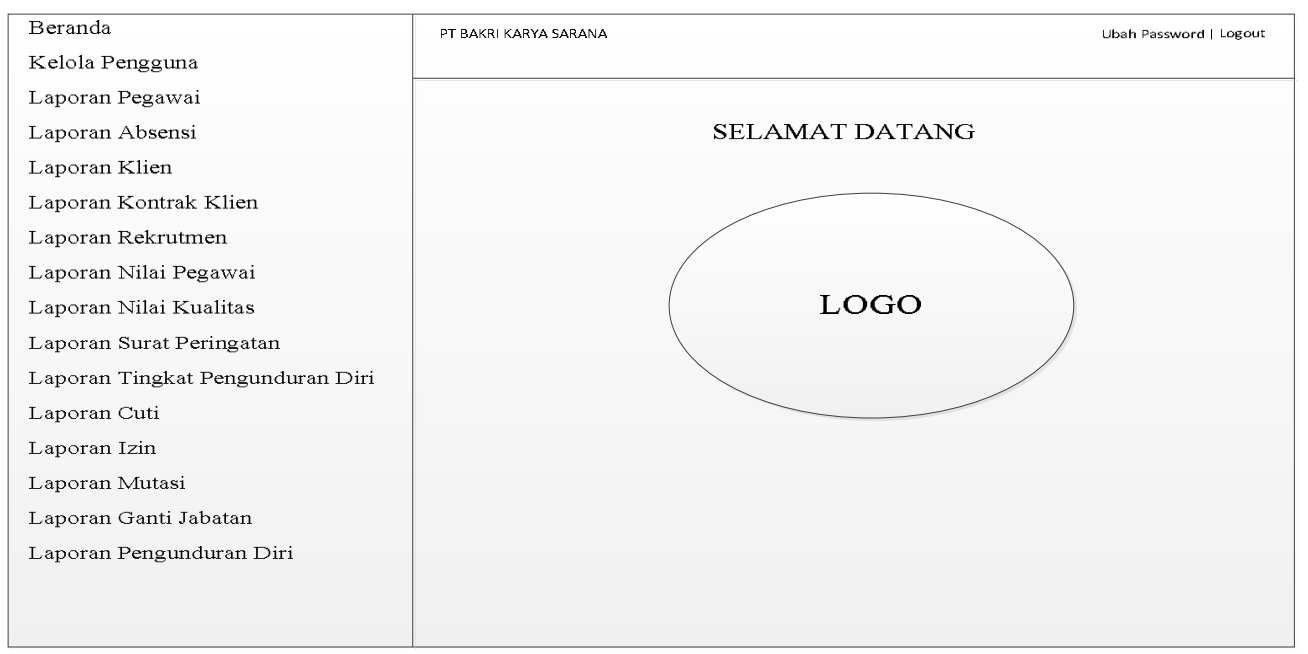

Gambar 15. Rancangan Antarmuka Beranda Hak Akses Direktur 


\subsubsection{Rancangan Antarmuka Beranda Hak Akses HRD}

Rancangan antarmuka beranda hak akses HRD ini adalah halaman utama yang menunjukkan hak akses HRD, dimana HRD berhak mengakses kelola pegawai, kelola posisi, kelola klien, kelola kontrak klien, kelola outsourcing, kelola mutasi, kelola ganti jabatan, kelola pengunduran diri, validasi pengunduran diri, kelola cuti, validasi cuti, kelola izin, validasi izin, kelola kriteria penilaian, lihat rekrutmen, laporan absensi, laporan surat peringatan, laporan nilai kualitas dan laporan nilai pegawai.

\begin{tabular}{l|l|} 
Beranda & FT GAKRI KARYA SAFANA \\
Kelola Pegawai & \\
Kelola Posisi & \\
Kelola Klien \\
Kelola Kontrak Klien \\
Kelola Rekrutmen \\
Kelola Izin \\
Validasi Izin \\
Kelola Cuti \\
Validasi Cuti \\
Kelola Mutasi \\
Kelola Ganti Jabatan \\
Kelola Pengunduran Diri \\
Validasi Pengunduran Diri \\
Kelola Kriteria Penilaian \\
Laporan Absensi \\
Laporan Nilai Pegawai \\
Laporan Nilai Kualitas \\
Laporan Surat Peringatan
\end{tabular}

Gambar 16. Rancangan Antarmuka Beranda Hak Akses HRD

\subsubsection{Rancangan Antarmuka Beranda Hak Akses Pengawas}

Rancangan antarmuka beranda hak akses pengawas ini adalah halaman utama yang menunjukkan hak akses pengawas, dimana pengawas berhak mengakses kelola absensi, kelola surat peringatan, kelola nilai pegawai, pengajuan cuti, pengajuan izin dan pengajuan pengunduran diri.

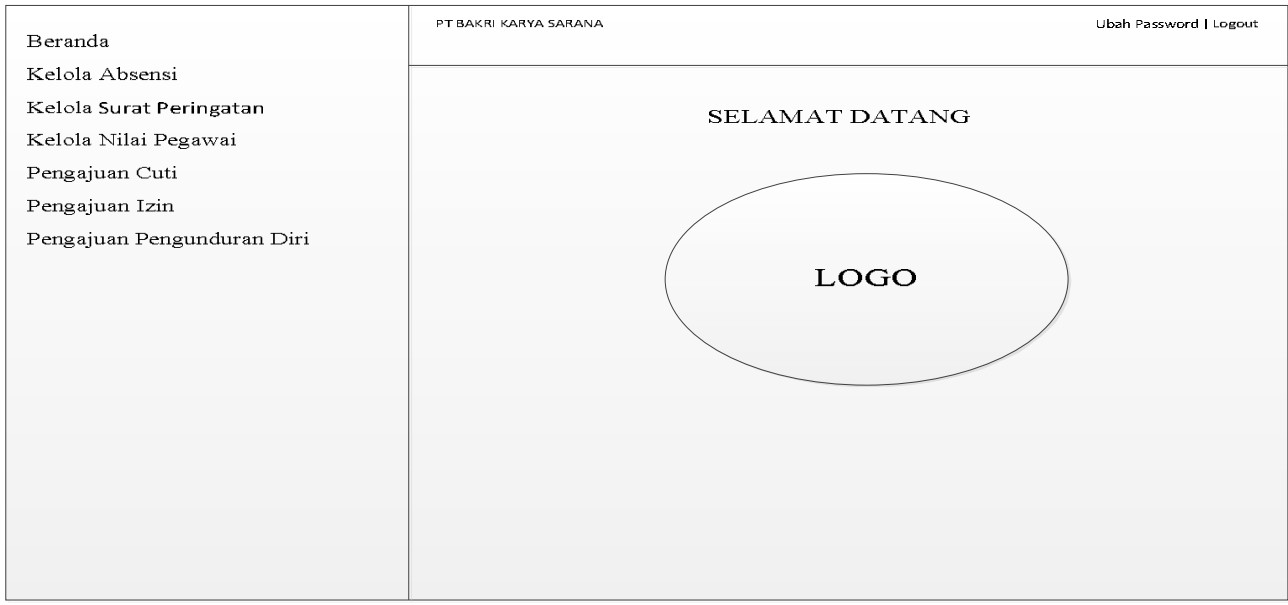

Gambar 17. Rancangan Antarmuka Beranda Hak Akses Pengawas 


\subsubsection{Rancangan Antarmuka Beranda Hak Akses Pegawai}

Rancangan antarmuka beranda hak akses pegawai ini adalah halaman utama yang menunjukkan hak akses pegawai, dimana pegawai berhak mengakses pengajuan izin, pengajuan cuti, pengajuan pengunduran diri, lihat absensi, lihat surat peringatan dan lihat nilai pegawai.

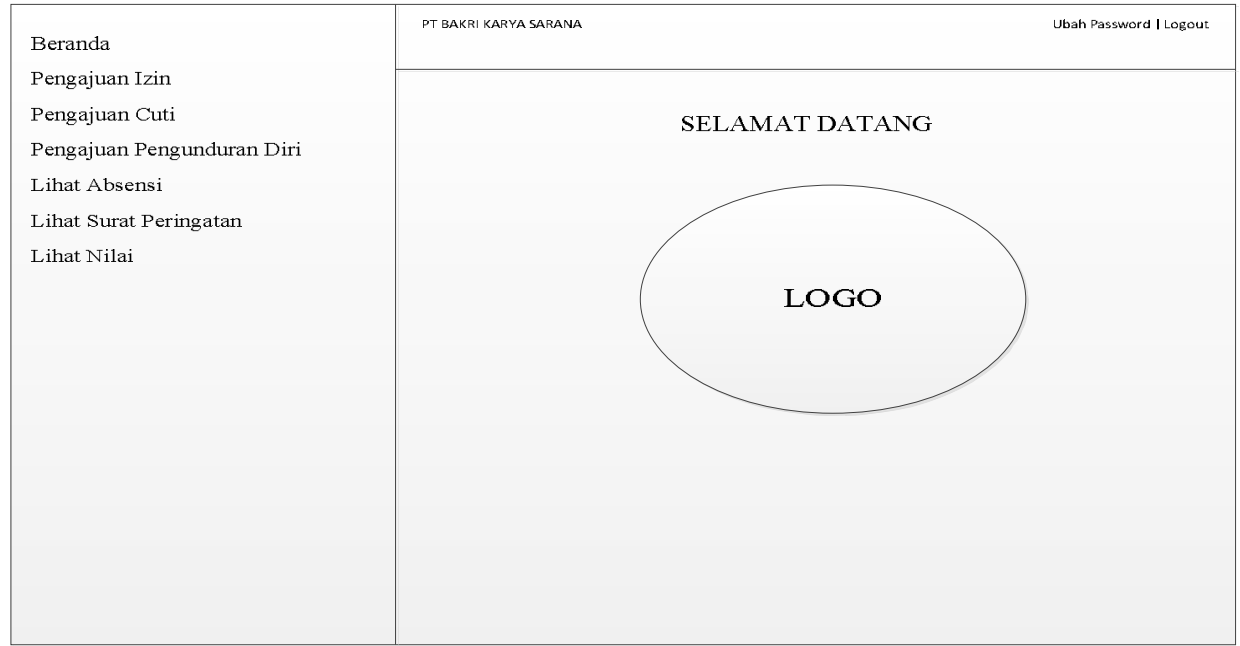

Gambar 18. Rancangan Antarmuka Beranda Hak Akses Pegawai

\subsubsection{Rancangan Antarmuka Beranda Hak Akses Bagian Keuangan}

Rancangan antarmuka beranda hak akses bagian keuangan ini adalah halaman utama yang menunjukkan hak akses bagian keuangan, dimana bagian keuangan berhak mengakses laporan yang berkaitan dengan gaji pegawai antara lain laporan absensi, laporan izin, laporan mutasi, laporan ganti jabatan, laporan pengunduran diri dan laporan pegawai.

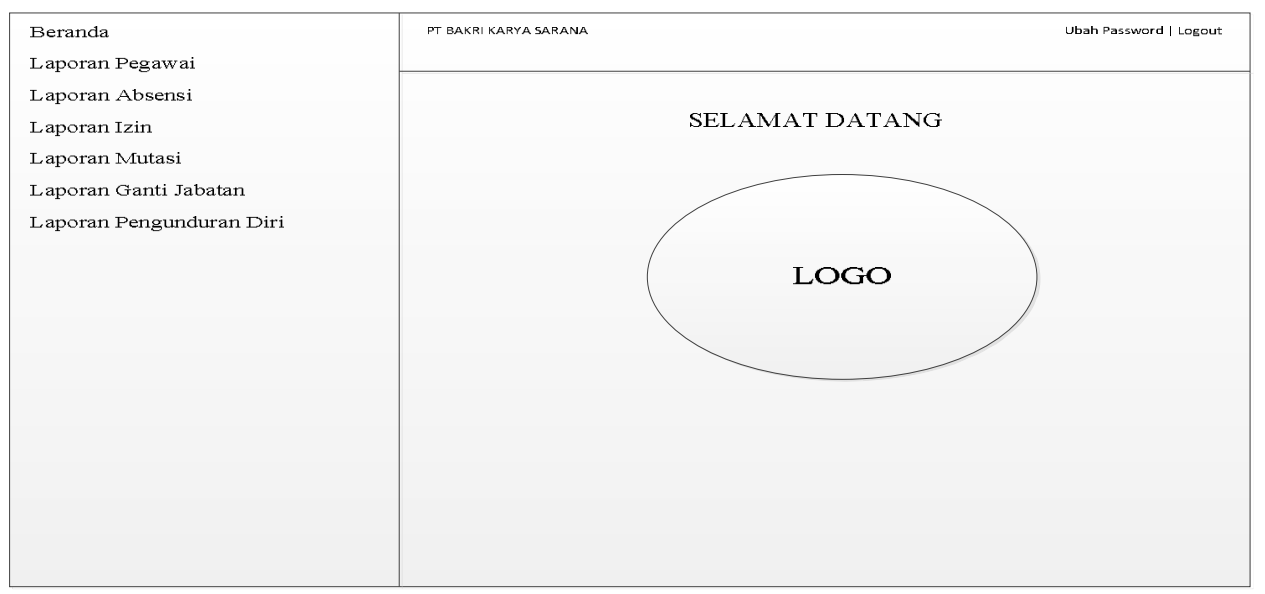

Gambar 19. Rancangan Antarmuka Beranda Hak Akses Bagian Keuangan

\subsubsection{Rancangan Antarmuka Beranda Hak Akses Admin BPJS}

Rancangan antarmuka beranda hak akses admin BPJS ini adalah halaman utama yang menunjukkan hak akses admin BPJS, dimana admin BPJS berhak mengakses laporan pegawai, laporan pegunduran diri, laporan mutasi dan laporan ganti jabatan. 


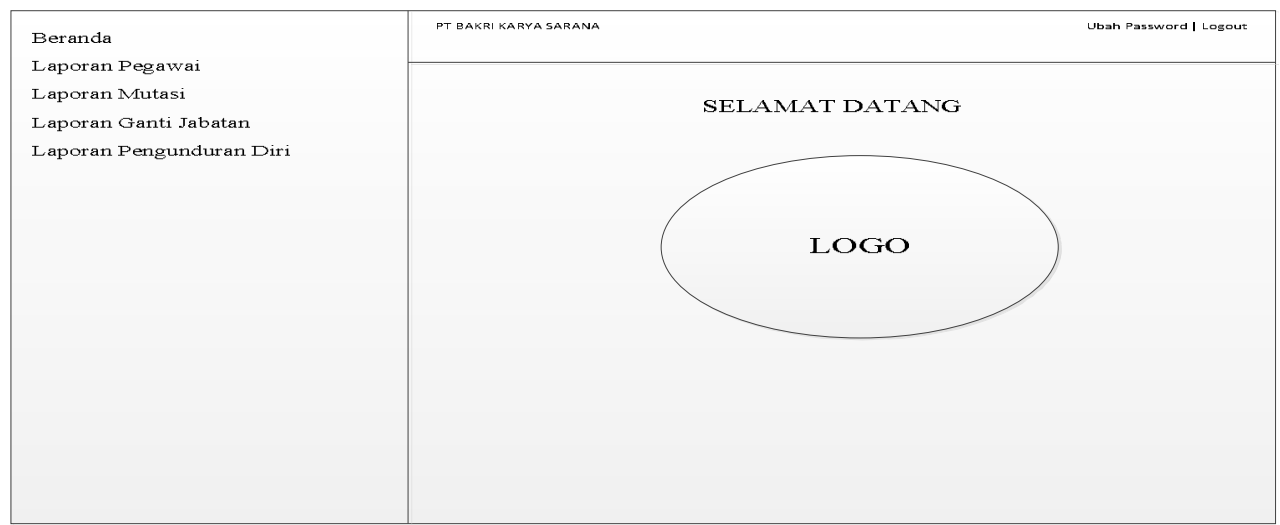

Gambar 20. Rancangan Antarmuka Beranda Hak Akses Admin BPJS

\section{KESIMPULAN}

1. Sistem yang dirancang ini diharapkan dapat mengatasi permasalahan dalam pengelolahan perekrutan sampai dengan pengunduran diri pegawai.

2. Sistem yang dirancang ini diharapkan dapat mengurangi terjadinya kesalahan pada proses perhitungan cuti dan proses laporan.

3. Sistem yang dirancang ini diharapkan dapat mempermudah pegawai dalam mengajukan cuti, izin dan pengunduran diri dan mempermudah calon pegawai yang ingin melamar pekerjaan di PT Bakri Karya Sarana Batam untuk memasukan berkas lamarannya.

4. Sistem yang dirancang ini membantu pengawas dalam mengabsen pegawai lapangan, mengelola nilai pegawai dan menginformasikan surat peringatan yang didapat perpegawai ke HRD dan direktur dengan lebih cepat.

5. Sistem yang dirancang ini dapat membantu klien untuk memberikan penilaian kualitas kepada seluruh pegawai yang dioutsourcingkan di tempat mereka dan informasi penilaian kualitas dari klien dapat diterima dengan cepat dan akurat oleh HRD dan direktur

6. Sistem yang dirancang dapatmembantu direktur, bagian keuangan dan admin BPJS untuk mendapatkan hasil laporan dengan lebih cepat dan lebih akurat.

\section{SARAN}

1. Rancangan yang telah dibuat ini sebaiknya ditambahkan lagi baik dari segi tampilan maupun fungsionalitasnya, sehingga lingkupnya bisa lebih besar lagi tidak hanya sebatas pegawai lapangan saja tetapi seluruh pegawai yang ada di PT Bakri Karya Sarana.

2. Perlu ditambahkan rancangan penggajian pegawai.

3. Pada rekrutmen perlu ditambahkan rancangan seleksi penerimaan pegawai baru sehingga tidak hanya sebatas seleksi berkas lamaran.

4. Pada penilaian pegawai perlu ditambahkan penilaian pegawai untuk jabatan pengawas dan pada absensi juga perlu ditambah fitur untuk absensi pengawas. 


\section{DAFTAR PUSTAKA}

[1] Undang-undang No.13 Tahun 2003, “Undang-Undang No.13 Th,” No. 1, pp. 1-34.

[2] R. F. Wahyuddin, 2014, "Pengaruh Penerapan Promosi Jabatan dan Demosi Jabatan Terhadap Prestasi Kerja Pada PT. Asindo Makassar, UIN Alauddin Makassar.

[3] J. L. Whitten, L. D. Bentley, and K. C. Dittman. 2004, Metode Desain dan Analisis Sistem, 6th ed. Andi, Yogyakarta.

[4] H. Al Fatta. 2007, Analisis dan Perancangan Sistem Informasi, Andi, Yogyakarta.

[5] A. Rossa and M. Salahuddin. 2013, Rekayasa Perangkat Lunak Terstruktur dan Berorientasi Objek. Informatika, Bandung. 